\title{
Strength Prediction Model of a Particle-Reinforced Shellproof Ceramic Composite
}

\author{
X. H. Ni, ${ }^{1}$ C. Chen, X. Q. Liu, and S. Q. Zhang \\ Mechanical Engineering College, Shijiazhuang, China \\ 1 jxxynxh@163.com
}

УДК 539.4

\section{Модель прогнозирования прочности пуленепробиваемых керамических композиционных материалов, упрочненных частицами}

\author{
К. Х. Ни ${ }^{1}$, Ч. Чен, к. к. Лиу, Ш. к. Жанг \\ Машиностроительный колледж, Шиджиажуанг, Китай
}

\begin{abstract}
На основе микроструктуры пуленепробиваемого керамического композичионного материала, упрочненного мелкими частицами, и характера его внутрикристаллического разрушения разработана модель разрушения при скоплении дислокаций, т.е. исследован механизм образования, роста и слияния трещин. При разработке модели разрушения при распространении трещины учитывали совместное влияние прочессов выкрашивания мелких частии и растрескивания крупных частиц. Изучено влияние относительного объема частии и диаметра матричного зерна на сопротивление разрушению. Экспериментальные результаты показали, что данная модель прогнозирования прочности является эффективной и общеприменимой.
\end{abstract}

Ключевые слова: прочность, пуленепробиваемый керамический материал, частица, скопление дислокаций, распространение трещины.

Introduction. Ceramics has become a popular shellproof material due to its low density, good energy-absorbing ability, as well as high wear resistance and dynamics characteristics. However, brittleness of ceramics limits its application. Therefore, ceramics can be reinforced by ceramic [1] or metal [2] particles. The particle-reinforced shellproof ceramic composites have been widely used due to their isotropic properties under high temperature, high stress and severe erosion conditions, as well as for their improved toughness and thermal dynamics characteristics. Their applications can be found in aerospace, hot engine, and energy conversion devices. The suitability of isotropic matrix composite depends on the microstructure characteristics, second phase distribution and content [3-8]. The failure of composite is a micromechanical damage evolution process, so its mechanical property is closely related to the microstructure and fracture feature of composite. Recently, the brittle matrix composites gained notable progress in research of synthetic methods, producing the improved mechanical properties and microstructures. Some failure criterions for ceramic matrix composites have been developed [9-11]. The macromechanical strength model of fiber eutectics and particle-reinforced composite ceramics was developed by considering a random orientation and length of fiber eutectics and the stress concentration due to the dislocation pile-up on the fiber-matrix interface [12]. The micromechanical strength of particles in composite ceramic with a partial debonding interphase was obtained via the equivalent stress of the particle in the threephase cell [13]. 
To date, the research of particle-reinforced shellproof ceramic composite is limited to material preparation and experimental analysis. No theoretical study on its mechanical property has been found in literature. The failure mechanism of this composite material is not clear. To address these issues, we aim to develop the failure analysis of shellproof ceramic composite containing reinforcing particles.

1. Dislocation Pile-Up Fracture Model of the Small Grain Ceramic Composite. The microscopic fracture appearance of a small-grain $(5 \mu \mathrm{m})$ shellproof ceramic composite is shown in Fig. 1. The brittle intergranular fracture and cleavage fracture appear in the fracture morphology. The intergranular brittle regions illustrate that microscopic plastic deformation occurs in a tiny limited area, which is caused by the aggregated microcracks that surround the particles, leading to the arc-type crack generation due to their interconnections. On the other hand, micro-yielding results in formation of microcracks, which are typically formed at the boundary between a deforming particle and nondeforming matrix grain, and the crack propagates rapidly along the particle. With and arc-type crack extension, the matrix area between the cracks decreases, while the stress in the matrix increases. With increased stress, some slip systems in matrix are initiated and turn into dislocation sources. Then macrocracks are formed by the pile-up dislocations at the matrix grain boundaries. Eventually, the matrix cleavage fracture leads to the material failure.
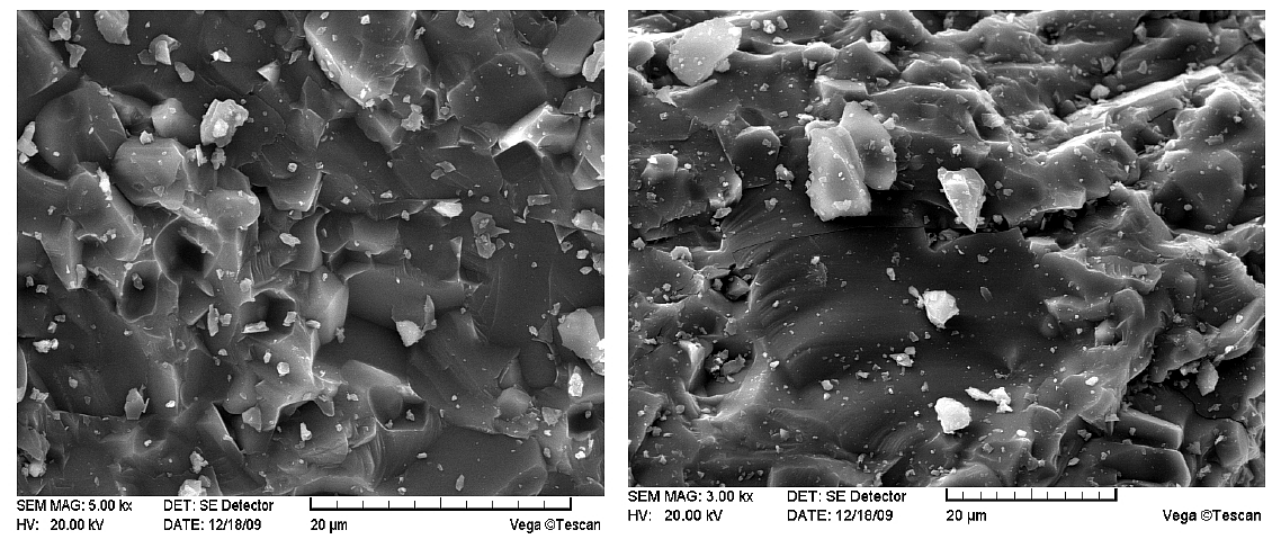

Fig. 1. Fracture morphology of the small-grain ceramic composite.

Under the effect of shearing stress, dislocations slip along slip plane and pile up in matrix grain boundary. With the increasing of shearing stress, dislocation source amplifies the dislocation and moves forward continually along the slip plane. Then dislocation piled-up group forms within matrix grain boundaries. Considering the resistance $\tau_{i}$ of crystal lattice against dislocation motion, dislocation amount $n$ in the dislocation pile-up group is related to the external shear stress $\tau$ and the length of slippage system, which can be expressed [14] as $n=\frac{\pi d \tau}{\mu_{0} \boldsymbol{b}}$, where the slip distance is taken as the crystal grain diameter $d$, and $\boldsymbol{b}$ is the Burgers vector. Dislocation in dislocation piled-up group is not uniformly distributed. The dislocation density is higher near the boundary. Resulting from piled-up dislocation, there is a force acting on the crystal boundary, which is equal to $\tau^{\prime}=n \tau=\frac{k \pi d \tau^{2}}{\mu \boldsymbol{b}}$. Due to the stress concentration before leading dislocation, there is a stress field around the stress concentration. The hypothesis that there is a point $P$ with a distance $r$ from the leading dislocation, the tensile stress at point $P$ perpendicular to $r$ direction, 
which is induced by the stress filed, can be written as $\sigma_{t}=\frac{3}{2} \tau \sqrt{\frac{d}{r}} \sin \alpha \cos \frac{\alpha}{2}$. Let $\frac{d \sigma_{t}}{d \alpha}=0$, we have, $\alpha_{m}=70.5^{\circ}$. Thus, the maximum tensile stress can be calculated as follows:

$$
\sigma_{t \max }=\frac{3}{2} \tau \sqrt{\frac{d}{r}} \sin \alpha_{m} \cos \frac{\alpha_{m}}{2}=2 \tau \sqrt{\frac{d}{3 r}} .
$$

The theoretic fracture strength of ceramic matrix is [15] $\sigma_{t h}=\sqrt{\frac{E_{0} \gamma_{0}}{a_{0}}} . E_{0}$ and $\gamma_{0}$ are the elastic modulus and free surface energy of ceramic matrix, respectively, while $a_{0}$ is lattice constant. Letting $\sigma_{t \max }=\sigma_{t h}$, the ultimate shear stress is determined as follows: $\tau_{u}=\frac{1}{2} \sqrt{\frac{3 E_{0} \gamma_{0}}{d}}$. Under the action of the far-field uniaxial tensile stress $\sigma$, and supposing 1 -axis is along the direction of the applied load, the maximum shear stress can be obtained [16]:

$$
\tau_{\max }=\left[\frac{2 A}{1-(3 f / 4 \pi)^{2 / 3}}+B\right] \frac{\sigma}{2},
$$

where $f$ is the volume fraction of reinforcing particles, while $A$ and $B$ are coefficients related to elastic constants, given by Liu [16]. When $\tau_{\max }=\tau_{u}$, the fracture strength of the small-grain ceramic composite can be obtained

$$
\sigma_{u 1}=\frac{1-\left(\frac{3 f}{4 \pi}\right)^{2 / 3}}{2 A+B\left[1-\left(\frac{3 f}{4 \pi}\right)^{2 / 3}\right]} \sqrt{\frac{3 E_{0} \gamma_{0}}{d}} \quad\left(d \leq d_{0}\right) .
$$

When the ceramic matrix is fractured, coalescence of arc-type microcracks occurs around the reinforcing particles. So the reinforcing particles will pull out as the small-grain ceramic composite fractures. Value of $d_{0}$ is denoted as the maximum diameter for reinforcing particles pulling-out.

2. Crack Extension Fracture Model of the Large Grain Ceramic Composite. The fracture morphology of the large-grain $(40 \mu \mathrm{m})$ ceramic composite is shown in Fig. 2.

As can be seen from this figure, there are no dimpled patterns observed at the SEM fracture surface, while the reinforcing particles have been broken and the fracture surface of the matrix is microscopically irregular. Within an individual matrix grain, the fracture propagates along several different cleavage planes. Such a micrograph indicates that firstlt the reinforcing particle cracking forms a crack source, and then it propagates into the matrix. There are more crystallographic planes in the large matrix grain, fracture occurs preferentially in certain crystallographic planes where the required tensile stress to overcome the atomic bonds is the minimal. The topographical features of the fracture surface show that in the material the transcrystalline crack propagates across crystallographically equivalent planes in grains oriented differently with respect to the tensile axis. For the large-grain ceramic composite, fracture is caused by the propagation of cracks when the large particles crack under the applied stress. But in the large-grain ceramic composite, particle sizes are different. The small particles will be pulled out as the large particles crack. 

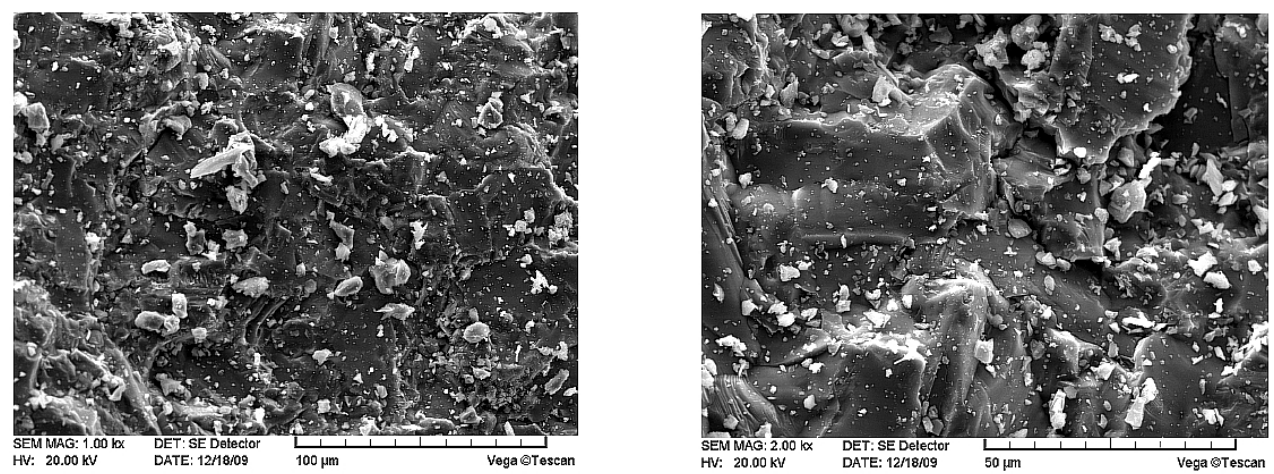

Fig. 2. Fracture morphology of the large-grain ceramic composite.

Essentially, this fracture description states that fracture occurs when the energy release rate accompanying crack extension is greater than the inherent force resisting this extension, and vice versa. The crack-resisting term is the matrix toughness $G_{C 0}$. The following relation between the crack extension stress and crack size can be obtained:

$$
\sigma_{f}=\sqrt{\frac{E_{0} G_{C 0}}{\pi c}}
$$

The hypothesis that the bearing area of composite is $A_{C}$, so the matrix net area can be determined by [16]

$$
A_{m}=A_{C}\left[1-(3 f / 4 \pi)^{2 / 3}\right] \text {. }
$$

One can reasonably assume that fracture occurs when the average stress of the matrix net area is equal to the crack extension stress. By equating these stresses, one can find that crack propagation occurs at the nominal stress

$$
\sigma_{c}=\frac{1}{A}\left[1-\left(\frac{3 f}{4 \pi}\right)^{2 / 3}\right] \sqrt{\frac{E_{0} G_{C 0}}{\pi c}}
$$

Equation (4) is used to determine the fracture stress caused by reinforcing particles cracking. While the large particles crack, the initial crack size of the ceramic composite is that of reinforcing particle, i.e., $c=d$. For different sizes of reinforcing particles in the large-grain ceramic composite, the small reinforcing particles will pull out as the large reinforcing particles crack. The fracture stress caused by small reinforcing particles pulling-out is shown in Eq. (3). Considering this two fracture mechanisms, the fracture strength of the ceramic composite can be expressed as

$$
\sigma_{u 2}=\sigma_{u 1}+\left\{\frac{1}{A}\left[1-\left(\frac{3 f}{4 \pi}\right)^{2 / 3}\right] \sqrt{\frac{E_{0} G_{C 0}}{\pi d}}-\sigma_{u 1}\right\} \sqrt{\frac{d-d_{0}}{d_{c}-d_{0}}} \quad\left(d \geq d_{0}\right),
$$

where $d_{c}$ is the minimum diameter for particles cracking. As been noted in Eq. (5), the size of preexisting defects is smaller than that of grains. The initial crack size of the ceramic composite is that of reinforcing particle. If not, the fracture of the ceramic composite is caused by the propagation of preexisting cracks, while the fracture strength is given by Eq. (4). 
3. Results and Discussion. As mentioned earlier, the fracture strength can be obtained via Eq. (3) for the small-grain ceramic composite and via Eq. (5) for large-grain one (assuming the size of preexisting defects is smaller than that of grains). For the small-grain ceramic composite, the microyielding at the boundary between a deforming particle and nondeforming matrix grain results in the formation of microcracks. Some slip systems in the matrix are initiated and become dislocation sources. Then the pile-up dislocations at the matrix grain boundaries lead to the material failure. Reinforcing particles will pull out as the small grain ceramic composite fractures. For the large-grain ceramic composite, reinforcing particle cracking forms a crack source, then it propagates into the matrix. The fracture strength is determined by two fracture mechanisms, i.e., small reinforcing particles' pulling-out and large reinforcing particles' cracking.

The maximum shear stress of the matrix is the primary factor of the small-grain ceramic composite fracture. The tensile stress of the matrix along the loading direction is that of the large-grain ceramic composite fracture. The maximum shear stress and tensile stress are interrelated to the elastic constants and volume fractions of the reinforcing particles and matrix.

For the small-grain shellproof ceramic composite, $E_{0}=420 \mathrm{GPa}, v_{0}=0.173, \gamma_{0}=$ $4 \mathrm{~J} / \mathrm{m}^{2}, E_{p}=156 \mathrm{GPa}, v_{p}=0.28$, and $d=3.5 \mu \mathrm{m}$. According to Eq. (3), the variation of fracture strength with volume fraction of reinforcing particles is shown in Fig. 3. For the large-grain shellproof ceramic composite, $G_{C 0}=60 \mathrm{~J} / \mathrm{m}^{2}, d_{0}=7.5 \mu \mathrm{m}, d_{c}=40 \mu \mathrm{m}$, and $d=16 \mu \mathrm{m}$. Based on Eq. (5), the fracture strength depends on volume fraction of reinforcing particles, as is shown schematically in Fig. 4. In Figs. 3 and 4, the fracture strength $\sigma_{u}$ is plotted against volume fraction of reinforcing particles. It is found that the load-bearing matrix net area decreases with the increasing of volume fraction of reinforcing particles. The effective stresses in matrix increase with the increase in the volume fraction of reinforcing particles. From Figs. 3 and 4 it is seen that the volume fraction of reinforcing particles has a less manifested effect on the fracture strength of the large-grain ceramic composite than that of the small-grain one.

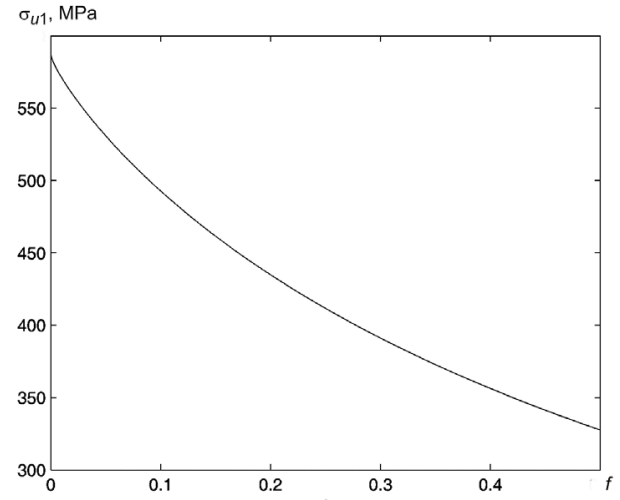

Fig. 3

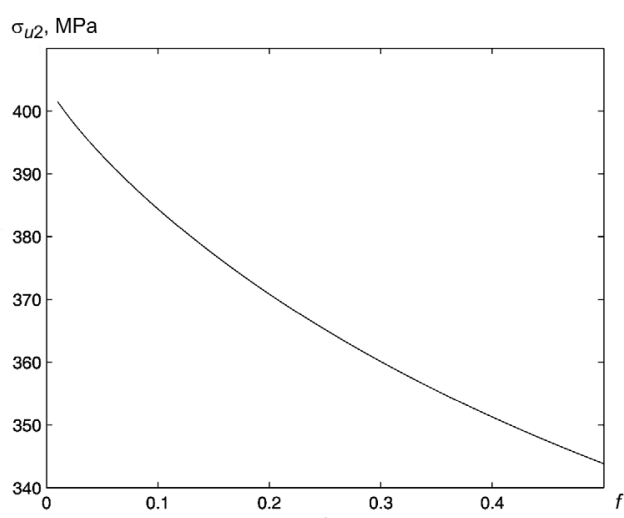

Fig. 4

Fig. 3. Fracture strength of the small-grain ceramic composite vs. volume fraction of reinforcing particles. Based on Eq. (3), it is assumed that $d=5 \mu \mathrm{m}$.

Fig. 4. Fracture strength of the large-grain ceramic composite vs. volume fraction of reinforcing particles. Based on Eq. (5), it is assumed that $d_{0}=7.5 \mu \mathrm{m}, d_{c}=40 \mu \mathrm{m}$, and $d=16 \mu \mathrm{m}$.

For the small-grain shellproof ceramic composites, $E_{0}=420 \mathrm{GPa}, v_{0}=0.173$, $\gamma_{0}=4 \mathrm{~J} / \mathrm{m}^{2}, E_{p}=156 \mathrm{GPa}, v_{p}=0.28$, and $f=0.1$. According to Eq. (3), the effect of grain diameter on fracture strength is illustrated in Fig. 5. For the large-grain shellproof 
$\mathrm{T}$ a b 1 e 1

\section{Comparison of Theoretical Results and Experimental Data}

\begin{tabular}{||l|c|c|c|c|c||}
\hline \hline Reinforcing particles' volume fraction $f$ & 0.2409 & 0.1621 & 0.1641 & 0.1715 & 0.2071 \\
\hline Grain diameter $d, \mu \mathrm{m}$ & 3.5 & 5.0 & 7.5 & 16.0 & 40.0 \\
\hline Strength $\sigma_{u}, \mathrm{MPa}$ (experimental data) & 389.47 & 380.21 & 353.53 & 375.02 & 360.31 \\
\hline Strength $\sigma_{u}, \mathrm{MPa}$ (theoretical results) & 411.43 & 382.54 & 376.10 & 387.50 & 370.40 \\
\hline
\end{tabular}

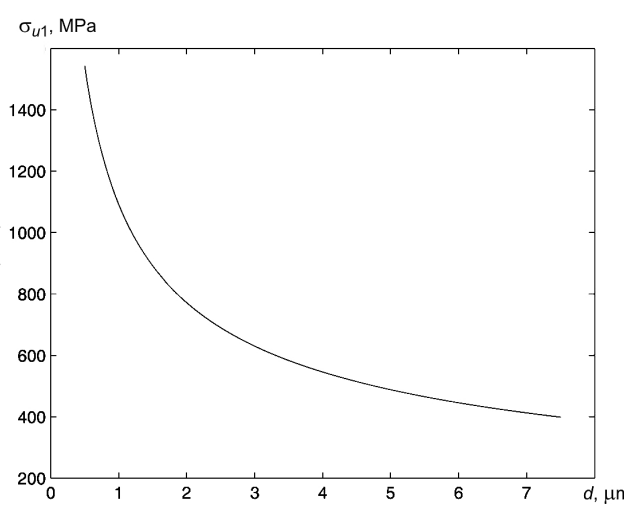

Fig. 5

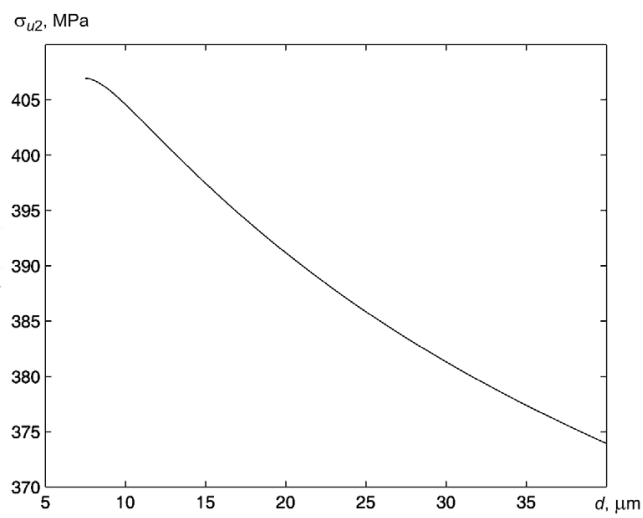

Fig. 6

Fig. 5. Schematic of fracture strength with grain size for the small-grain ceramic composite.

Fig. 6. Fracture strength variation with grain diameter for the large-grain ceramic composite.

ceramic composite, $E_{0}=420 \mathrm{GPa}, v_{0}=0.173, G_{C 0}=60 \mathrm{~J} / \mathrm{m}^{2}, E_{p}=156 \mathrm{GPa}, v_{p}=0.28$, $d_{0}=7.5 \mu \mathrm{m}, d_{c}=40 \mu \mathrm{m}$, and $f=0.1$. Based on Eq. (5), the fracture strength is affected by grain diameter, which is depicted in Fig. 6. As shown in Figs. 5 and 6, loss of fracture strength $\sigma_{u}$ correlates diameter, which is depicted in Fig. 6. As shown in Figs. 5 and 6, loss of fracture strength $\sigma_{u}$ correlates with the grain diameter. When $d \leq 2 \mu \mathrm{m}$, the strength is high. Since the grain diameter is small, the length of slippage system (for the small-grain ceramic composite) or the initial crack size (for the large-grain one) is small, leading to high strength. Analyzing Figs. 5 and 6, one can find that the fracture strength variation for the large-grain ceramic composite is less than that for the small-grain one.

The three-point bending test technique was used to measure the bending strength. The maximum tensile stress was found at the bar surface. The bend strength is equal to this stress at fracture. The theoretical results and experimental data for the fracture strength of shellproof ceramic composite are given in Table 1. The predicted fracture strength values exhibit a good agreement with five experimental data sets.

Conclusions. The effective stress field is determined using the proposed efficient and self-consistent method. The maximum shear and tensile stresses in the matrix net area are computed on the basis of the microstructure of a shellproof ceramic composite and the mechanism of formation, growth and coalescence of microcracks, with account for the microcrack nucleation at the reinforcing particle boundaries.

The fracture mechanism of the small-grain ceramic composite containing the reinforcing particles is investigated. The dislocation pile-up fracture model is developed based on the small reinforcing particle pulling-out. According to the complex effect of the small reinforcing particle pulling-out and large reinforcing particle cracking, the crack extension fracture model of the large-grain ceramic composite is developed. The influence 
of reinforcing particles' volume fraction and matrix grain diameter on the fracture strength is studied. The theoretical results show that the fracture strength decreases with the increasing volume fraction of the reinforcing particles. The loss of fracture strength is found to be correlated with the grain diameter. The three-point bending test technique was used to measure the bend strength. The predicted fracture strength values are in good agreement with five experimental datasets. The prediction range corresponds to the experimental field of interest.

Acknowledgment. This material is based upon work supported by the National Natural Science Foundation of China under Grant No. 11272355.

\section{Резюме}

На основі мікроструктури куленепробивного керамічного композиційного матеріалу, зміцненого дрібними частинками, і характеру внутрішньокристалічного руйнування розроблено модель руйнування при скупченні дислокацій, тобто досліджено механізм виникнення, росту і злиття тріщин. При розробці моделі руйнування при розповсюдженні тріщини враховували спільний вплив процесів викришування дрібних частинок і розтріскування великих. Вивчено вплив відносного об'єму частинок i діаметра матричного зерна на опір руйнуванню. Експериментальні дані показали, що запропонована модель прогнозування міцності є ефективною і загальновживаною.

1. D. M. Stump, "Spalling in zirconia-reinforced ceramics," Mech. Mater., 20, 305-313 (1995).

2. M. Wildan, H. J. Edrees, and A. Hendry, "Ceramic matrix composites of zirconia reinforced with metal particles," Mater. Chem. Phys., 75, 276-283 (2002).

3. H. J. Edrees, A. C. Smith, and A. Hendry, "A rule of mixtures model for sintering of particle-reinforced ceramic-matrix composites," J. Eur. Ceram. Soc., 18, 275-278 (1998).

4. J. L. Lagrange and Ph. Colomban, "Double particles reinforcement of ceramic-matrix composites prepared by a sol-gel route," Compos. Sci. Technol., 58, 653-658 (1998).

5. Y. S. Liu, L. F. Cheng, L. T. Zhang, et al., "Microstructure and properties of particle-reinforced silicon carbide and silicon nitride ceramic matrix composites prepared by chemical vapor infiltration," Mater. Sci. Eng. A, 475, 217-223 (2008).

6. M. Szafran, K. Konopka, E. Bobryk, and K. J. Kurzydlowski, "Ceramic matrix composites with gradient concentration of metal particles," J. Eur. Ceram. Soc., 27, 651-654 (2007).

7. I. E. Keimanis, "A review of issues in the fracture of interfacial ceramics and ceramic composites," Mater. Sci. Eng. A, 237, 159-167 (1997).

8. G. A. Gogotsi, "Fracture toughness of ceramic composites," Ceram. Int., 29, 777-784 (2003).

9. H.-Y. Yeh, H. C. Murphy, and H.-L. Yeh, "An investigation of failure criterion for new orthotropic ceramic matrix composite materials," J. Reinf. Plast. Comp., 28, No. 4, 441-459 (2009).

10. F. Pavia, A. Letertre, and W. A. Curtin, "Prediction of first matrix cracking in micro/nanohybrid brittle matrix composites," Compos. Sci. Technol., 70, No. 6, 916-921 (2010).

11. X. Q. Liu, X. H. Ni, Y. T. Liu, and B. H. Han, "Mesomechanical strength model of nano-fibers composite ceramics," Solid State Phenom., 121-123, 1157-1160 (2007). 
12. X. H. Ni, T. Sun, X. Q. Liu, et al. "Size dependent strength of fiber eutectics and transformation particles composite ceramic," Appl. Mech. Mater., 44-47, 2264-2268 (2011).

13. X. H. Ni, X. Q. Liu, B. H. Han, et al., "Micromechanical strength of particle in composite ceramic with partial debonding interphase," Adv. Mater. Res., 146-147, 366-369 (2011).

14. J. S. Zhao, Fracture Mechanics and Fracture Physics [in Chinese], 1st edition, Huazhong University of Science and Technology Press, Wuhan (2004).

15. T. H. Courtney, Mechanical Behavior of Materials, 1st edition, McGraw-Hill Education (Asia) and China Machine Press, Beijing (2004).

16. Q. X. Liu and J. F. Yang, "The ultimate stress of small grain shellproof ceramic composite," Appl. Mech. Mater., 121-126, 524-528 (2012).

Received 22. 11. 2013 